\title{
Effects of siRNA silencing on the susceptibility of the fish cell line CHSE-214 to Yersinia ruckeri
}

\author{
Simon Menanteau-Ledouble ${ }^{1^{*}}$ (D), Oskar Schachner ${ }^{1}$, Mark L. Lawrence ${ }^{2}$ and Mansour El-Matbouli ${ }^{1}$
}

\begin{abstract}
Yersinia ruckeri is a facultative intracellular enterobacterium mostly known as the causative agent of enteric redmouth disease in salmonid fish. In the present study, we applied RNA inhibition to silence twenty pre-selected genes on the genome of a fish cell line (CHSE-214) followed by a gentamicin assay to quantify the effect of silencing on the cells' susceptibility to infection and found that silencing of 18 out of 20 genes significantly reduced the number of $Y$. ruckeri recovered. These findings improve our understanding of the infection process by Y. ruckeri and of the interactions between this bacterial pathogen and host cells.
\end{abstract}

\section{Introduction, methods and results}

The enterobacterium Yersinia ruckeri is a major fish pathogen worldwide and has mostly been studied as the causative agent of enteric red-mouth disease in salmonid fish $[1,2]$. Several virulence factors have been described in Y. ruckeri (see reviews by Kumar et al. and Wrobel et al. $[1,3]) . Y$. ruckeri causes septicaemia and haemorrhages leading to high levels of mortality in infected fish $[1,2]$. The bacterium also has zoonotic potential and has been associated with topical infections in humans [4]. Like several other members of the genus Yersinia, Y. ruckeri has demonstrated the ability to invade non-professional phagocytic cells $[5,6]$, allowing the bacterium to access restricted nutrients and protecting it from the immune system. It might help the bacterium to cross epithelial membranes as is the case for other Yersiniaceae.

Two main mechanisms of entry have been described in bacteria, including Yersiniaceae. The zipper mechanism is initiated by the binding of the bacterial adhesins to specific molecules on the cell membrane (see the review on

*Correspondence: menanteaus@staff.vetmeduni.ac.at

${ }^{1}$ Clinical Division of Fish Medicine, University of Veterinary Medicine, Vienna, Austria

Full list of author information is available at the end of the article yersinia adhesins by Chauhan et al. [2]). In Y. pseudotuberculosis and $Y$. enterocolitica, two autotransporter proteins invasin (Inv) and Yersinia adhesin A (YadA) interact with integrin receptors $[7,8]$. Interactions of these bacterial proteins with receptors on the surface of the host's cells lead to the recruitment of more receptors, activation of Rac1 and cytoskeletal rearrangement culminating in the uptake of the bacterium [9]. Interestingly; while $Y$. ruckeri does not harbour a YadA equivalent, it is known to harbour two homologs of invasin: Y. ruckeri invasin (YrInv) and Y. ruckeri invasin-like molecule (YrIlm) [3]. Furthermore, several isolates of $Y$. ruckeri belonging to the O1 serotype also carry a cluster of fimbrial gene homologous to the STF cluster of $S$. typhimurium [10, 11]. However, this cluster is absent from the ATCC 29473 type strain studied here [11].

The other main mechanism of entry studied is the trigger mechanism that relies on effector proteins secreted through the type three and type four secretion system (T3SS and T4SS). Once inside the host's cells, these effector proteins interact with regulatory proteins in the host, in particular members of the Rho family (RhoGTPases Rac, Cdc42 or RhoG) [12], leading to a rearrangement of the cytoskeleton of the host cells and the uptake of the bacterium [12]. Intriguingly, the T3SS of Y. ruckeri

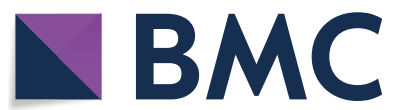

(c) The Author(s) 2020. This article is licensed under a Creative Commons Attribution 4.0 International License, which permits use, sharing, adaptation, distribution and reproduction in any medium or format, as long as you give appropriate credit to the original author(s) and the source, provide a link to the Creative Commons licence, and indicate if changes were made. The images or other third party material in this article are included in the article's Creative Commons licence, unless indicated otherwise in a credit line to the material. If material is not included in the article's Creative Commons licence and your intended use is not permitted by statutory regulation or exceeds the permitted use, you will need to obtain permission directly from the copyright holder. To view a copy of this licence, visit http://creativeco mmons.org/licenses/by/4.0/. The Creative Commons Public Domain Dedication waiver (http://creativecommons.org/publicdomain/ zero/1.0/) applies to the data made available in this article, unless otherwise stated in a credit line to the data. 
actually belongs to the Ysa family, a different family from the one most studied in Yersiniaceae and is more closely related to the T3SS carried on Salmonella pathogenicity island 1 (SPI-1) of Salmonella enterica [13, 14]. Among the proteins carried on SPI-1 is the chaperon Invasion protein B (InvB); SPI-1 is known to play a role in the intracellular invasion of S. enterica [15] so the Ysa of $Y$. ruckeri could plausibly be involved in intracellular invasion of Y. ruckeri. However, our knowledge of Ysa T3SS, and that of $Y$. ruckeri in particular is still very incomplete [10] and no conclusion is currently possible.

An important feature of both invasion mechanisms is that they require active uptake of the bacterium by the cell and it is possible to prevent host cells from internalising the bacteria, for example by treating them with chemical blockers [5, 6]. Similarly, silencing of host genes has been shown to inhibit bacterial internalisation. For example, 305 host genes have been associated with the ability of Listeria monocytogenes to invade cell cultures of drosophila SL2 cells and 86 genes necessary for invasion by Mycobacterium fortuitum [16]. In human macrophages, 270 molecules have been identified whose silencing affected the bacterial load of seven different field isolates of Mycobacterium tuberculosis [17]. Finally, 252 genes have been shown to be involved in the survival of Salmonella enterica serovar Typhimurium within the human epithelial cell line MCF-7 [18]. Among these genes, the most impactful were SEC22A, Rab1B and VPS33B that were involved in vesicle trafficking as well as ATP6VOD1, an ATPase involved in vacuole acidification and the iron transporter FTHL17. Interestingly, the authors noted a significant overlap between their findings and that reported by Kumar et al. for M. tuberculosis [17] suggesting that many of these targets are well conserved even between very evolutionary distant bacteria.

In the present study, we aimed to produce siRNA to silence 20 genes commonly involved in invasion by bacterial pathogens (see Additional file 1), including surface integrins since such molecules are often targeted by the invasin molecules expressed by other Yersiniaceae [2]. Other genes were cytoskeletal molecules and genes involved in vacuolar trafficking and maturation $[17,18]$ as well as agents of the cytoskeletal apparatus since this plays a central part in the internalization of bacteria through both zipper and trigger mechanisms [12]. The selection also included genes and pathways shared by $L$. monocytogenes, M. tuberculosis as well as S. typhimurium [16-18] since these pathways are used by such diverse facultative intracellular pathogens, they might also be involved in the intracellular invasion of $Y$. ruckeri.

The fish cell line Chinook Salmon Embryo (CHSE-214) was used since we wanted to investigate an epithelial cell line derived from salmonids. In previous experiments using multiple cell lines we showed that it was well suited for invasion by $Y$. ruckeri. PCR and sequencing were applied to confirm that the CHSE214 cells were indeed derived from Chinook salmon (Oncorhynchus tshawytscha). Similarly; the study focussed on the type strain ATCC 29473, a type strain belonging to biotype 1, since these experiments showed that it had a high potential for invasiveness [5].

\section{siRNA transfection}

Sequences for the siRNA were designed using the Silencer Select siRNA design algorithm. For the genes for which no O. tshawytscha sequences were available, sequences from other members of the Oncorhynchus genomes were used. Upon reception, the siRNA were resuspended to $20 \mu \mathrm{M}$ and stored at $-20{ }^{\circ} \mathrm{C}$ until use, according to the manufacturer's instructions.

CHSE-214 cells were grown in 24 well plates at $20{ }^{\circ} \mathrm{C}$ supplied with $1250 \mu \mathrm{L}$ Minimum Essential Medium (MEM-glutaMAX $^{\mathrm{TM}}$, Gibco, Thermo-Fisher Scientific, Waltham, USA) containing 2\% FBS, where they reached about $80 \%$ confluence 1 day after seeding. On the day of the assay, $8 \mu \mathrm{L}$ of the siRNA solution was added to $400 \mu \mathrm{L}$ of Opti-MEM medium (Gibco). Seventy-two microliters of RNAiMax lipofectamine reagent (Sigma Aldrich, St Louis, USA) was diluted in $1200 \mu \mathrm{L}$ of Opti-MEM medium. The two solutions were mixed and incubated $5 \mathrm{~min}$ at room temperature. Afterwards, the culture medium on top of two adjacent rows of the 24 wells was replaced with $50 \mu \mathrm{L}$ of the solution and, after $20 \mathrm{~min}$, $450 \mu \mathrm{L}$ of fresh MEM-Glutamax medium was added.

Ambion $^{\circledR}$ Silencer $^{\circledR}$ Negative Control \#1 (ThermoFischer Scientific) was applied as a negative control. The cells were incubated at $20{ }^{\circ} \mathrm{C}$ and since the temperature commonly used for transfection was lower than for other cell lines, incubation time was extended to 3 days.

\section{Bacterial invasion assay}

The gentamicin assay was performed as previously described [5]. Briefly, Y. ruckeri ATCC 29473 was cultivated overnight in brain heart infusion (BHI, Oxoid, Thermo-Fisher Scientific). Optical density of the culture was assessed by spectrophotometry (Eppendorf Biophotometer, Hamburg, Germany) and adjusted to an optical density of .5 at $600 \mathrm{~nm}$. Bacteria were pelleted by centrifugation at $3220 \mathrm{~g}$ and $20^{\circ} \mathrm{C}$ (in an Eppendorf Centrifuge $5810 \mathrm{R}$ ) and resuspended in 10 times the original volume of MEM-Glutamax. Then, the culture medium in the leftmost row was replaced by this bacterial solution and the bacteria were left to interact with the cells for $5 \mathrm{~h}$ at room temperature. In the other row, the medium was replaced by fresh MEM-glutamax without bacteria. After that time, the medium was removed, the cells were 
washed three times with phosphate buffered saline (PBS) and a fresh volume of MEM-glutamax, supplemented with the antibiotic gentamicin (Sigma-Aldrich) at a concentration of $100 \mu \mathrm{g} / \mathrm{mL}$ was added to the wells. The antibiotic was left to act for $4 \mathrm{~h}$. Afterwards the cells were washed twice with PBS before replacing the medium supplemented with 1\% Triton-X (Sigma-Aldrich). After 10 min of exposure to the detergent, the cells were triturated with a micropipette and serially diluted from $10^{-1}$ to $10^{-4}$ before being plated onto Brain heart infusion agar (BHIA, Oxoid). Each of the three wells represented a biological replicate and each dilution was plated in technical quadruplicates, meaning that 48 plates were inoculated for each siRNA. The agar plates were incubated at $22{ }^{\circ} \mathrm{C}$ until clear colonies were visible and counted (generally after $48 \mathrm{~h}$ ) and the average CFU per $\mathrm{mL}$ value was calculated.

\section{Controls}

For each siRNA, the cells numbered 1D, 3D and 5D were left un-inoculated in each 24 well plate then lysed and plated to act as a negative control and detect any contamination of the reagents. Similarly, the cells in the wells 2D, 4D and 6D were also left un-exposed to the bacteria and a trypan blue assay was performed to rule-out a toxic effect of the siRNA silencing: The cells were washed three times in PBS, then .2\% Trypan Blue (Gibco, .4\% diluted 1:1 in PBS) was added. After 1 min, fixation was performed with $4 \%$ formalin for $10 \mathrm{~min}$. The cells were then rinsed until any trace of blue dye had disappeared. The plates were kept at $4{ }^{\circ} \mathrm{C}$ until quantification of the cells using an inverted microscope (Leica DM IRB, Wetzlar, Germany). One hundred cells were counted and the number of blue stained cells among them was recorded. The procedure was repeated 4 more times for each culture unit to result in 5 percentage values for each siRNA. These were then compared to the survival of the control cells without siRNA to confirm that the silencing procedure did not have a toxic effect. In no instances did these numbers differ significantly from that of the control.

\section{Preparation of the CDNA samples}

Finally, the cells in the rightmost row for each treatment were lysed in buffer RLT (Qiagen, Hilden, Germany). The cell suspension was homogenised using QIAshredder columns (Qiagen) and centrifugation at 145000 RPM for two minutes at room temperature using MiniSpin tabletop centrifuge (Eppendorf). Afterwards, the RNA were extracted using the Rneasy mini kit (Qiagen). RNA were immediately quantified using a Nanodrop machine (Thermo-Fisher) and cDNA were immediately synthesised using Iscript kits (Bio-Rad) in a C1000 Touch thermocycler (Bio-Rad, Hercules, USA). cDNA were stored at $4{ }^{\circ} \mathrm{C}$ until use.

\section{RT-qPCR}

After obtention of these cDNA, RT-qPCR were performed to compare the level of expression between the genes targeted by siRNA and the control and confirm that the siRNA had successfully silenced the expression of these genes. The primer sequences used are listed in Table 1 and ubiquitin and elongation factor 1-alpha primers designed by Peña et al. [19] were used for the housekeeping reference genes.

Genomic DNA was extracted from CHSE-214 cells using the DNeasy kit (Qiagen) according to the manufacturer's instructions. End point PCR was performed using these primers to confirm the optimal annealing temperature, afterwards the PCR products were purified with a QIAquick gel purification kit (Qiagen). Products' concentrations were measured using a nanodrop, then adjusted to $10 \mathrm{ng} / \mu \mathrm{L}$. Afterwards, serial dilution was performed to produce concentrations ranging from $10^{-1}$ to $10^{-4} \mathrm{ng} / \mu \mathrm{L}$. qPCR were then performed on these serial dilutions as well as the cDNA produced as described in the previous section. Relative gene expression levels of the silenced genes were calculated using the $2^{-\Delta \Delta \mathrm{Ct}}$ method and converted into percentage for clarity in order to confirm the efficacy of the silencing. Serial dilutions were used to calculate the $\mathrm{R}^{2}$ and efficiency of the qPCR and confirm that these were above .9 and between 95 and 100\%, respectively for every qPCR.

\section{Results}

RT-qPCR confirmed the efficiency of the silencing since all treated genes had a lower expression level compared to the control (see Additional file 2).

Silencing of every one of the twenty tested genes resulted in some reduction of the number of bacteria recovered from CHSE-214 cells at the end of the assay. However, this reduction was only statistically significant in 18 out of 20 genes (Table 2).

The two genes whose silencing had the strongest statistical effect were lama2 which encodes a homolog of the extracellular matrix protein laminin subunit $\alpha-2$ (Laminin 2) that play an important role in cell adhesion as well as the Ras-related C3 botulinum toxin substrate 1 (Rac1) gene that encodes an important regulatory G protein. Silencing of these genes reduced the number of surviving bacteria to 3.0 and $3.1 \%$ of the corresponding control, respectively $(P<0.001)$.

Other genes whose silencing had a great impact included the myotubularin protein 2 and the Equilibrative nucleoside transporter 1 , a glycoprotein that mediates the cellular uptake of nucleosides from the 
Table 1 Primer sequences for the RT-qPCR confirmation of the siRNA silencing

\begin{tabular}{|c|c|}
\hline \multirow[t]{2}{*}{ Ubiquitin* } & GGAAAACCATCACCCTTGAG* \\
\hline & ATAATGCCTCCACGAAGACG** \\
\hline \multirow[t]{2}{*}{ Elongation Factor 1 alpha* } & GTCTACAAAATCGGCGGTAT* \\
\hline & CTTGACGGACACGTTCTTGA* \\
\hline \multirow[t]{2}{*}{ Protein kinase C } & TTGTTTGGCGGACTCCTGAA \\
\hline & CCACGCCGAAAACAATCTCC \\
\hline \multirow[t]{2}{*}{ Rab-1A } & AACCCCACCAACACCTCTAC \\
\hline & GCACACACACACAACTTCTTTC \\
\hline \multirow[t]{2}{*}{ SEC22b-B } & AGAGAGGAGAGGAGATAGGG \\
\hline & TGGATAGAATGTGAGACCAGA \\
\hline \multirow[t]{2}{*}{ Vacuolar ATP synthase subunit A } & CCGCTGAGGACTTCCGATAAAC \\
\hline & ACAGCCTTCCATAGCATTGCAC \\
\hline \multirow[t]{2}{*}{ VPS-associated protein } & ATCCACAACCTGACTGCCTACC \\
\hline & CTCTCGCTGCTCTTGATGAAC \\
\hline \multirow[t]{2}{*}{ Rho1-GTPase } & TAGCCCCAGTTTGCTCTTCG \\
\hline & GCTGTCTCGTTCACTGGTCA \\
\hline \multirow[t]{2}{*}{ Ube213 } & ААССССАССТССТTТСТСТС \\
\hline & TTCACTAAGTCCCCTTGTTCC \\
\hline \multirow[t]{2}{*}{ Sumo 2} & TCCACCACAGAACCAATACC \\
\hline & CAAAACAGGAAGGAAACAAAGG \\
\hline \multirow[t]{2}{*}{ Equilibrative nucleoside transporter 1} & ACGTCCGTGTTAAATGCTC \\
\hline & AСAАААТСТСТССТССССТС \\
\hline \multirow[t]{2}{*}{ Integrin $\beta$-1 precursor } & ACCAATCCTACCCCCTATCC \\
\hline & AGACCTCCCTCATTGTGTCG \\
\hline \multirow[t]{2}{*}{ Actin } & CCAAGCAGGAATACGACGAG \\
\hline & GCGTGGCAAAAAAAGTCCAG \\
\hline \multirow[t]{2}{*}{ Rac1 } & ACTCACCCCCATTACCTACC \\
\hline & СTGCTCCAATCTCTTTTGCC \\
\hline \multirow[t]{2}{*}{ SDC42 } & AGAGGGGAAGGAATCAACAG \\
\hline & ATGACAGGCAGGTAGGAGAG \\
\hline \multirow[t]{2}{*}{ Rho GTPase-activating prot. } & CAGAAGAAAATGAGCAAAGACC \\
\hline & CCTGAGAACTACTGTCCACC \\
\hline \multirow[t]{2}{*}{ Laminin 2} & GCGAATCAGAACCCTCAAC \\
\hline & GCAGATACACATCCCTCCAAC \\
\hline \multirow[t]{2}{*}{$\beta$-Cadherin } & TCCCTCAGTTCCCTCAACTC \\
\hline & TСТСAАТССТСТССТССТСС \\
\hline \multirow[t]{2}{*}{ Myotubularin-related protein 2} & TCAAGCGGAATACAAAAGACAG \\
\hline & ССАСТСТСТTCAACTCCTCATC \\
\hline \multirow[t]{2}{*}{ MaPK } & TTCACTTCTCAAACCCCAAAC \\
\hline & CGCTCAAAGGACAAACCAC \\
\hline \multirow[t]{2}{*}{ Caspase I precursor } & GTGGAACAACAGGAAACAAAG \\
\hline & TGATGGCAGTAGAACAGGG \\
\hline \multirow[t]{2}{*}{ Cyclin D1 } & GCTGTCCTGTATGCTCTCTC \\
\hline & CCCAAACCATTCCATTCTTCTC \\
\hline
\end{tabular}

The two first (with an asterisk) primer pairs are the housekeeping genes and were designed by Peña et al. [19].

environment (3.8\% and $4.9 \%$ compared to the control, respectively; $P<0.001)$. Followed by the precursor for the transmembrane receptor integrin $\beta-1$ that acts alongside integrin alpha 1 and integrin alpha 2 to form collagen receptors involved in cell adhesion $5.0 \%$ of control, $P<0.001)$ and actin $(6.3 \%$ compared to control; $P<0.001)$. Finally, three more notable genes included the one encoding for the regulator protein kinase $\mathrm{C}$ (9.3\% of the control; $P<0.001$ ), alongside sumo2, that encodes a ubiquitin like-protein that binds to target protein as part of a post-translational modification system and plays a role in nuclear transport $(9.3 \%$ of the control; $P<0.001)$ as well as the gene encoding the Ras related protein Rab1A that is involved in the regulation of vesicular transport, in particular in relation with the Golgi apparatus (11.3\% compared to the control; $P<0.001$ )

Conversely, the two genes whose silencing had no significant effect on the bacterial invasion included the gene encoding the caspase I precursor; caspase I plays an important role in cellular immunity by activating immune-related proteins such as interleukin by proteolytic cleavage $(59.1 \%$ of the control, $P=1.000)$. The second gene encoded the ubiquitin conjugating enzyme Ube2L3 (55.7\% of the control; $P=.831$ ) that contributes to the ubiquitination of target proteins prior to degradation.

\section{Discussion}

Genes whose silencing had the most significant effect

Lama2 was the gene whose silencing had the strongest statistical effect. This result is comparable to that of van Wijk et al. who reported that silencing of lama2 protected hamster ovary $(\mathrm{CHO})$ cells from invasion by several isolates of Streptococcus and Staphylococcus aureus [20]. Previously, a modified Western-blot procedure had also shown that Lama2 was a substrate for the adhesion of $Y$. enterocolitica, including for isolates of the bacterium that did not express YadA, demonstrating that this binding was YadA independent [21]. This is particularly relevant as YadA is also absent from $Y$. ruckeri and it is therefore plausible that laminin could constitute an important substrate for the binding of $Y$. ruckeri's adhesins.

Silencing of the Rac1 gene had an equally strong effect. Rac1 is a member of the Rho family of GTPases and plays a central role regulating cytoskeleton rearrangement. This regulator has previously been involved in intracellular invasion of the enterobacteriaceae Salmonella typhimurium [22] and is targeted by the effector protein IpgB1 of Shigella [23]. In a previous experiment, we reported that the inhibitor of Rac1 N-acetylcysteine completely inhibited entrance of $Y$. ruckeri into CHSE-214 cells [5], which is very consistent with our current findings.

Another gene whose silencing had a high effect was the myotubularin protein 2. Myotubularins are tyrosine 
Table 2 Genes investigated in this study and silencing effect

\begin{tabular}{|c|c|c|c|c|}
\hline Gene & $\begin{array}{l}\text { Average number } \\
\text { of bacteria } \\
\text { recovered }\end{array}$ & $\begin{array}{l}\text { Mean Difference in number } \\
\text { of bacteria recovered compared } \\
\text { with control }\end{array}$ & $\begin{array}{l}\text { Sig. of the effect } \\
\text { of the silencing }\end{array}$ & $\begin{array}{l}\text { Number of bacteria recovered } \\
\text { as percentage of those recovered } \\
\text { in the untreated control (\%) }\end{array}$ \\
\hline Scrambled RNA control & $3.13 E+05$ & & & 100.0 \\
\hline $\operatorname{Sec} 22 B$ & $1.05 E+05$ & $2.08 \mathrm{E}+05^{*}$ & .004 & 33.4 \\
\hline ATPAse subunit F & $1.05 E+05$ & $2.07 E+05^{*}$ & .001 & 33.7 \\
\hline VPS11 & $5.96 \mathrm{E}+04$ & $2.53 \mathrm{E}+05^{*}$ & .001 & 19.1 \\
\hline Rho GTPase & $1.27 \mathrm{E}+05$ & $1.86 \mathrm{E}+05^{*}$ & .012 & 40.5 \\
\hline Ube2EL3 & $1.74 \mathrm{E}+05$ & $1.39 E+05^{a}$ & $.831^{\mathrm{a}}$ & 55.7 \\
\hline sumo2 & $2.98 \mathrm{E}+04$ & 2.83E+05* & .001 & 9.5 \\
\hline Nucleoside transporter 1 & $1.54 \mathrm{E}+04$ & $2.97 \mathrm{E}+05^{*}$ & .001 & 4.9 \\
\hline Integrin beta 1 & $1.57 \mathrm{E}+04$ & $2.97 \mathrm{E}+05^{*}$ & .001 & 5.0 \\
\hline Actin & $1.98 \mathrm{E}+04$ & $2.93 \mathrm{E}+05^{*}$ & .001 & 6.3 \\
\hline Racl & $9.83 \mathrm{E}+03$ & $3.03 E+05^{*}$ & .001 & 3.1 \\
\hline CDC42 & $2.78 \mathrm{E}+04$ & $2.85 \mathrm{E}+05^{*}$ & .001 & 8.9 \\
\hline arhgap18 & $2.61 \mathrm{E}+04$ & $2.87 \mathrm{E}+05^{*}$ & .001 & 8.3 \\
\hline lama2 & $9.43 E+03$ & $3.03 \mathrm{E}+05^{*}$ & .001 & 3.0 \\
\hline$\beta$-Cadherin & $3.04 \mathrm{E}+04$ & $2.82 \mathrm{E}+05^{*}$ & .001 & 9.7 \\
\hline Myotubularin protein 2 & 1.17E+04 & $3.01 \mathrm{E}+05^{*}$ & .001 & 3.8 \\
\hline MApk14A & $2.70 E+04$ & $2.86 \mathrm{E}+05^{*}$ & .001 & 8.6 \\
\hline Caspase I precursor & $1.85 \mathrm{E}+05$ & $1.28 \mathrm{E}+05^{\mathrm{a}}$ & $1.000^{\mathrm{a}}$ & 59.1 \\
\hline Cyclin D1 & $1.03 E+05$ & $2.09 E+05^{*}$ & .005 & 33.1 \\
\hline ProtKinC & $2.91 \mathrm{E}+04$ & $2.84 \mathrm{E}+05^{*}$ & .001 & 9.3 \\
\hline Rabl & $3.54 \mathrm{E}+04$ & $2.77 \mathrm{E}+05^{*}$ & .001 & 11.3 \\
\hline Total & $8.22 \mathrm{E}+04$ & & & \\
\hline
\end{tabular}

Silencing effect was determined by comparing the number of bacteria recovered at the end of the gentamicin assay. Significant difference between the results and the control are further indicated with an asterisk.

${ }^{a}$ Genes (ubiquitin conjugating enzyme Ube2L3 and caspase I precursor) represent genes whose silencing did not significantly impact the gentamicin assay.

phosphatases and, while their role during bacterial infections has been poorly characterised, genome wide screening of Thornbrough et al. showed that silencing myotubularin protein 3 protected Michigan Cancer Foundation-7 (MCF-7) cells from infection by Salmonella typhimurium [18]. Indeed, among the 252 susceptibility factors identified in this study, myotubularin protein 3 was among the ones that had the strongest impact on intracellular bacterial infection [18].

Similarly, Equilibrative nucleoside transporter 1 is a member of a well-conserved family of transmembrane proteins. Pathogenic intracellular bacteria are known to scavenge nucleotide from their environment and therefore a reduction in the nutrients available to the bacterium could explain the effects of silencing this gene.

Another molecule whose silencing had a significant effect on the cells' sensitivity to infection was the precursor for integrin $\beta-1$. Integrins are trans-membrane receptors and their role in cell adhesion to the extra-cellular matrix is well known. Moreover, integrins $\beta-1$ have been well studied as targets of the adhesin molecules of Yersinia sp., including Y. pseudotuberculosis [24] and Y. enterocolitica [25]. As such, they play a central role in the use of the zipper mechanisms by these bacteria to gain intracellular entry. Notably, Y. ruckeri possesses two adhesins homologous to invasin (YrInv and Yrilm) [3]. The finding that this target is also important for $Y$. ruckeri suggests that this bacterium might gain intracellular entry through the zipper mechanism, targeting integrin- $\beta$ molecules using invasin-like adhesins, in a manner similar to that of $Y$. pseudotuberculosis and $Y$. enterocolitica.

Similarly, silencing of the actin gene also had a very notable effect. Actin is a central component of the cytoskeleton that plays a critical role in both the trigger and zipper mechanism [12].

Finally, two more genes whose silencing had a statistically significant effect were the genes coding for the protein kinase $\mathrm{C}$, a regulatory protein overseeing a large number of varied functions, including signal transduction as well as the expression of the cytoplasmic tyrosine kinase, Focal Adhesion Kinase (FAK) and actin rearrangement [26]. Previously, protein kinase $\mathrm{C}$ activity has shown an inverse correlation with the 
uptake of L. monocytogenes by murine macrophages, as well as a positive correlation with the escape of these bacteria from the macrophage endosomes [27] and it has been shown that protein kinase $C$ recruitment in lipid rafts was induced by Enterohemorrhagic E. coli $\mathrm{O} 157: \mathrm{H7}$. In the present study, silencing of the gene encoding for protein kinase $\mathrm{C}$ resulted in a strong decrease of the cell susceptibility to bacterial infection $(P<0.001)$.

Finally, silencing of the Rab1A molecule also had a notable effect on the cell's susceptibility to $Y$. ruckeri infection. Rab1A is a member of the Rab family, small GTPases acting together as network involved in the regulation of vesicular transport. Rab1A is specifically required for the microtubule-based motility of murine endocytic vesicles [28] and silencing of Rab1b was shown to lead to a reduced growth of $S$. enterica Typhimurium within MCF-7 cells [18]. Rab1A's isoform Rab1b is also known to be necessary for the survival of $Y$. pestis within murine macrophages [29].

\section{Genes whose silencing had no significant effect}

Two genes were found for which silencing did not result in a significant reduction in the number of recovered bacteria. The first was the caspase I precursor. Caspases take part in the cellular immune response and play an important role in regulating apoptosis and Caspase I is known to be inhibited by the YopJ effector molecule of $Y$. pestis [30]. If it is similarly targeted by a virulence factor of $Y$. ruckeri, this could explain why it is not necessary for this bacterium's invasion.

Finally, the other gene whose silencing had no statistically significant effect was the gene coding for the ubiquitin conjugating enzyme Ube2L3 (55.7\% of the control; $P=.831$ ). A similar protein, Ube2L6 was among the new factors reported by Thornbrough et al. as involved in the intracellular infection by S. typhimurium [18]. Ube2L3 is also known to be a substrate for the effector protein YopM of $Y$. pseudotuberculosis, however, there was no other information to suggest a similar involvement of Ube2L3 in the invasion of Y. ruckeri.

\section{Supplementary information}

Supplementary information accompanies this paper at https://doi. org/10.1186/s13567-020-00760-6.

Additional file 1. Genes selected for this experiment with a brief description of their expected role in bacterial invasion and the rational for their selection.

Additional file 2. Relative gene expression of the silenced genes compared to the control, as assessed by RT-qPCR. Relative gene expression levels of the silenced genes were calculated using the $2^{-\Delta \Delta C t}$ method and ubiquitin and elongation factor 1-alpha were used as reference genes according to Peña et al. [19]. Average results compared to both house-keeping genes were then calculated and relative expression values were then converted into percentage of the expression into the silenced genes compared to the control for clarity. Greyed out cells represent genes whose silencing did not significantly impact the gentamycin assay.

\section{Abbreviations}

Ail: Attachment invasion locus; BHI: Brain heart infusion; cDNA: Complementary DNA; CDC42: Cell division cycle 42; CHSE-214: Chinook Salmon Embryo; CFU: Colony forming unit; FAK: Focal adhesion kinase; FTHL17: Ferritin heavy chain like 17; MCF7: Michigan Cancer Foundation-7 cell line; MEM: Minimum essential medium; MS222: Tricaine methanesulfonate; Rac1: Ras-related C3 botulinum toxin substrate 1; RPM: Rotation per minute; RT-qPCR: Reverse transcription quantitative real-time PCR; SEC22A: Secretory protein 22A; SiRNA: Small interfering ribonucleic acid; SPI1: Salmonella pathogenicity island 1; T3SS: Type 3 Secretion System; T4SS: Type 4 Secretion System; VPS33B: Vacuolar protein sorting-associated protein 33B; Yop: Yersinia outer protein; YrInv: Yersinia ruckeri invasion; Yrllm: Yersinia ruckeri invasin-like molecule.

\section{Acknowledgements}

The authors wish to thank Noémie Ledouble for her assistance with the bibliographic section of the manuscript.

\section{Authors' contributions}

SML, MLL and MEL designed the experiment. OS and SML cultivated the cell lines and performed the transformations while SML performed the gentamicin assay, RT-qPCR and statistical analysis and wrote the manuscript. All authors read and approved the final manuscript.

\section{Funding}

This research was financed by the Austrian Science Funds (Fonds zur Förderung der wissenschaftlichen Forschung), Project P28837-B22. This funding body played no role in the design of the study or interpretation of data.

\section{Competing interests}

The authors declare that they have no competing interests.

\section{Author details}

${ }^{1}$ Clinical Division of Fish Medicine, University of Veterinary Medicine, Vienna, Austria. ${ }^{2}$ Feed the Future Fish Innovation Lab for Fish, Mississippi State, MS, USA.

Received: 12 November 2019 Accepted: 12 January 2020

Published online: 20 March 2020

\section{References}

1. Kumar G, Menanteau-Ledouble S, Saleh M, El-Matbouli M (2015) Yersinia ruckeri, the causative agent of enteric redmouth disease in fish. Vet Res 46:103

2. Chauhan N, Wrobel A, Skurnik M, Leo JC (2016) Yersinia adhesins: an arsenal for infection. Proteomics Clin Appl 10:949-963

3. Wrobel A, Leo JC, Linke D (2019) Overcoming fish defences: the virulence factors of Yersinia ruckeri. Genes 10:E700

4. De Keukeleire $S$, De Bel A, Jansen Y, Janssens M, Wauters $G$, Piérard D (2014) Yersinia ruckeri, an unusual microorganism isolated from a human wound infection. New Microbes New Infect 2:134-135

5. Menanteau-Ledouble S, Lawrence ML, El-Matbouli M (2018) Invasion and replication of Yersinia ruckeri in fish cell cultures. BMC Vet Res 14:81

6. Tobback E, Decostere A, Hermans K, Van den Broeck W, Haesebrouck F, Chiers K (2010) In vitro markers for virulence in Yersinia ruckeri. J Fish Dis 33:197-209

7. Grassl GA, Bohn E, Müller Y, Bühler OT, Autenrieth IB (2003) Interaction of Yersinia enterocolitica with epithelial cells: invasin beyond invasion. Int J Med Microbiol 293:41-54

8. Leibiger K, Schweers JM, Schütz M (2019) Biogenesis and function of the autotransporter adhesins YadA, intimin and invasin. Int J Med Microbiol 309:331-337 
9. Ribet $D$, Cossart P (2015) How bacterial pathogens colonize their hosts and invade deeper tissues. Microbes Infect 17:173-183

10. Guijarro JA, García-Torrico Al, Cascales D, Méndez J (2018) The infection process of Yersinia ruckeri: reviewing the pieces of the Jigsaw puzzle. Front Cell Infect Microbiol 8:218

11. Cascales D, Guijarro JA, García-Torrico Al, Méndez J (2017) Comparative genome analysis reveals important genetic differences among serotype $\mathrm{O} 1$ and serotype $\mathrm{O} 2$ strains of $\mathrm{Y}$. ruckeri and provides insights into host adaptation and virulence. MicrobiologyOpen 6:e00460

12. Cossart P, Sansonetti PJ (2004) Bacterial invasion: the paradigms of enteroinvasive pathogens. Science 304:242-248

13. Liu T, Wang K-Y, Wang J, Chen DF, Huang XL, Ouyang P, Geng Y, He Y, Zhou Y, Min J (2016) Genome sequence of the fish pathogen Yersinia ruckeri SC09 provides insights into niche adaptation and pathogenic mechanism. Int J Mol Sci 17:557

14. Wang K, Liu T, Wang J, Chen DF, Wu XJ, Jiang J, Liu JX (2015) Complete genome sequence of the fish pathogen Yersinia ruckeri strain SC09, isolated from diseased Ictalurus punctatus in China. Genome Announc 3:e01327-e01414

15. Ehrbar K, Friebel A, Miller SI, Hardt W-D (2003) Role of the Salmonella pathogenicity island 1 (SPI-1) protein InvB in type III secretion of SopE and SopE2, two Salmonella effector proteins encoded outside of SPI-1. J Bacteriol 185:6950-6967

16. Agaisse H, Burrack LS, Philips JA, Rubin EJ, Perrimon N, Higgins DE (2005) Genome-wide RNAi screen for host factors required for intracellular bacterial infection. Science 309:1248-1251

17. Kumar D, Nath L, Kamal MA, Varshney A, Jain A, Singh S, Rao KV (2010) Genome-wide analysis of the host intracellular network that regulates survival of Mycobacterium tuberculosis. Cell 140:731-743

18. Thornbrough JM, Hundley T, Valdivia R, Worley MJ (2012) Human genome-wide RNAi screen for host factors that modulate intracellular Salmonella growth. PLoS One 7:e38097

19. Peña AA, Bols NC, Marshall SH (2010) An evaluation of potential reference genes for stability of expression in two salmonid cell lines after infection with either Piscirickettsia salmonis or IPNV. BMC Res Notes 3:101

20. van Wijk XM, Döhrmann S, Hallström BM, Li S, Voldborg BG, Meng BX, McKee KK, van Kuppervelt TH, Yurchenco PD, Palsson BO, Lewis NE, Nizet V, Esko JD (2017) Whole-genome sequencing of invasion-resistant cells identifies laminin a2 as a host factor for bacterial invasion. mBio 8:e02128-e03016
21. Flügel A, Schulze-Koops H, Heesemann J, Kühn K, Sorokin L, Burkhardt $H$, von der Mark K, Emmrich F (1994) Interaction of enteropathogenic Yersinia enterocolitica with complex basement membranes and the extracellular matrix proteins collagen type IV, laminin-1 and -2, and nidogen/ entactin. J Biol Chem 269:29732-29738

22. Criss AK, Ahlgren DM, Jou TS, McCormick BA, Casanova JE (2001) The GTPase Rac1 selectively regulates Salmonella invasion at the apical plasma membrane of polarized epithelial cells. J Cell Sci 114:1331-1341

23. Ohya K, Handa Y, Ogawa M, Suzuki M, Sasakawa C (2005) IpgB1 is a novel Shigella effector protein involved in bacterial invasion of host cells. Its activity to promote membrane ruffling via Rac1 and Cdc42 activation. J Biol Chem 280:24022-24034

24. Leong JM, Fournier RS, Isberg RR (1990) Identification of the integrin binding domain of the Yersinia pseudotuberculosis invasin protein. EMBO $J$ 9:1979-1989

25. Wiedemann A, Linder S, GrassI G, Albert M, Autenrieth I, Aepfelbacher M (2001) Yersinia enterocolitica invasin triggers phagocytosis via beta1 integrins, CDC42Hs and WASp in macrophages. Cell Microbiol 3:693-702

26. Sukumaran SK, Prasadarao NV (2002) Regulation of protein kinase C in Escherichia coli K1 invasion of human brain microvascular endothelial cells. J Biol Chem 277:12253-12262

27. Wadsworth SJ, Goldfine H (2002) Mobilization of protein kinase C in macrophages induced by Listeria monocytogenes affects its internalization and escape from the phagosome. Infect Immun 70:4650-4660

28. Mukhopadhyay A, Nieves E, Che F-Y, Wang J, Jin L, Murray JW, Gordon K, Angeletti RH, Wolkoff AW (2011) Proteomic analysis of endocytic vesicles: Rab1a regulates motility of early endocytic vesicles. J Cell Sci 124:765-775

29. Connor MG, Pulsifer AR, Price CT, Abu Kwaik Y, Lawrenz MB (2015) Yersinia pestis requires host Rab1b for survival in macrophages. PLoS Pathog 11:e1005241

30. Lilo S, Zheng Y, Bliska JB (2008) Caspase-1 activation in macrophages infected with Yersinia pestis KIM requires the type III secretion system effector YopJ. Infect Immun 76:3911-3923

\section{Publisher's Note}

Springer Nature remains neutral with regard to jurisdictional claims in published maps and institutional affiliations.
Ready to submit your research? Choose BMC and benefit from:

- fast, convenient online submission

- thorough peer review by experienced researchers in your field

- rapid publication on acceptance

- support for research data, including large and complex data types

- gold Open Access which fosters wider collaboration and increased citations

- maximum visibility for your research: over $100 \mathrm{M}$ website views per year

At BMC, research is always in progress.

Learn more biomedcentral.com/submissions 